\title{
Amlodipine in Hypertension : 24 - Hour Blood Pressure Control, Hormonal and Renal Effects
}

\author{
Endang Susalit
}

\begin{abstract}
Abstrak
Penelitian ini bertujuan untuk menilai efek pemberian 5-10 mg amlodipin dengan dosis sekali sehari terhadap profil tekanan darah selama 24 jam, hormonal, dan hemodinamik ginjal pada penderita hipertensi esensial. Penelitian dilakukan secara terbuka, nonkomparatif, yang terdiri atas dua fase, yaitu fase plasebo selama dua minggu dilanjutkan dengan fase pengobatan amlodipin selama delapan minggu. Pada akhir fase plasebo dan fase pengobatan dilakukan pemeriksaan tekanan darah selama 24 jam, aktivitas renin plasma, peptid natriuretik atrial dan insulin plasma, jumlah ekskresi katekholamin dalam urin-24 jam, laju filtrasi glomerulus, dan aliran plasma ginjal efektif. Tiga puluh penderita (19 pria dan 11 wanita) dengan umur rerata 47.8 tahun (kisaran: 24-65 tahun) mengikuti penelitian ini. Sesudah pengobatan amlodipin selama delapan minggu tekanan darah rerata 24-jam \% simpang baku menurun dari $160,6 \%$ $15,9 / 103,6 \% 5,5$ menjadi $134,3 \% 12,7 / 81,7 \% 4,0 \mathrm{mmHg}(p<0,001)$ tanpa merubah pola sirkadian. Sesudah pengobatan tidak terjadi perubahan denyut jantung yang bermakna. Sesudah pengobatan, aktivitas renin plasma rerata \% simpang baku meningkat dari $1,74 \%$ 0,56 menjadi $1,89 \% 0,54 \mathrm{ng} / \mathrm{m} / \mathrm{jam}$, peptid natriuretik atrial plasma dari 52,1\% 12,6 menjadi 54,7\% $11,0 \mathrm{pg} / \mathrm{ml}$, insulin plasma dari $19,9 \% 4,2$ menjadi $21,0 \% 4,3 \mu \mathrm{U} / \mathrm{ml}$, laju filtrasi glomerulus dari $112,1 \% 11,5$ menjadi $115,8 \% 11,6 \mathrm{ml} / \mathrm{menit}$, dan aliran plasma ginjal efektif dari 552,0\% 55,8 menjadi 595,2\% 52,9 ml/menit $(p<0,05$ sampai $<0,001)$. Ekskresi katekolamin dalam urin-24 jam pada fase plasebo dibandingkan dengan fase pengobatan tidak berbeda bermakna. Sebagai kesimpulan, amlodipin dengan dosis sekali sehari efektif dalam menurunkan tekanan darah selama 24 jam tanpa merubah variasi sirkadian, serta tidak menimbulkan perubahan kadar hormon vasopresor dan perubahan derajat fungsi ginjal yang bermakna dalam klinik.
\end{abstract}

\begin{abstract}
The purpose of the present study is to evaluate the effects of amlodipine once daily on 24-hour BP control, hormonal and renal hemodynamic parameters, in patients with essential hypertension. This study was an open non-comparative study of amlodipine 5-10 $m g$ once daily, which consisted of two phases: a 2-week placebo run-in period and an 8-week active treatment with amlodipine. At the end of placebo phase and at the end of treatment phase, we measured ambulatory BP for 24-hour period, PRA, plasma insulin and ANP, 24-hour urinary output of catecholamines, GFR and ERPF. Thirty patients (19 men and 11 women) with a mean age of 47.8 years (range of 24-65 years) were recruited into this study. After 8 weeks of amlodipine therapy, mean 24 - hour BP \% SD was reduced from $160.6 \% 15.9 / 103.6 \% 5.5$ to $134.3 \% 12.7 / 81.7 \% 4.0 \mathrm{mmHg}(p<0.001)$ without altering the circadian pattern. No significant changes in HR was observed. After treatment, mean PRA \% SD increased from $1.74 \% 0.56$ to $1.89 \% 0.54 \mathrm{ng} / \mathrm{mLh}$, plasma ANP from $52.1 \% 12.6$ to $54.7 \% 11.0 \mathrm{pg} / \mathrm{ml}$, plasma insulin from $19.9 \% 4.2$ to $21.0 \% 4.3 \mu \mathrm{U} / \mathrm{ml}$, GFR from $112.1 \% 11.5$ to $115.8 \% 11.6 \mathrm{ml} / \mathrm{min}$ and ERPF from $552.0 \% 55.8$ to $595.2 \% 52.9 \mathrm{ml} / \mathrm{min}(p<0.05$ to $<0.001)$. Urinary catecholamines did not differ significantly between the placebo and amlodipine phases. In conclusion, amlodipine once daily is an effective antihypertensive throughout 24 hours without altering the circadian variation, and has no clinically significant effect on pressor hormones nor renal function.
\end{abstract}

Keywords : Hypertension, amlodipine, 24-hour blood pressure control, hormonal and renal effects

Amlodipine is a new calcium antagonist of the dihydropyridine class. It has a relatively high oral bioavailability (60-65\%) and a long elimination halflife of 35 to 48 hours. Therefore it can be given once daily for an effective 24-hour control of blood pressure. ${ }^{1}$ The long elimination half-life permits this drug

Department of Internal Medicine, Faculty of Medicine, University of Indonesia/Dr. Cipto Mangunkusumo Hospital, Jakarta, Indonesia to produce low fluctuations of piasma levels as well as antihypertensive effect. ${ }^{2}$ Amlodipine also has a slow onset of action, leading to a smooth antihypertensive effect, minimal acute vasodilatory side effects and lack of reflex activation of the sympathetic nervous system. ${ }^{3-5}$ In addition, calcium antagonist may have some renal protective effects, ${ }^{6}$ with neutral metabolic effects. 7,8

The purpose of the present study was to evaluate the effects of amlodipine single daily dose on : (a) BP control throughout 24 hours using ambulatory blood 
pressure monitor ( ABPM ), (b) patient's tolerability, (c) some hormonal and biochemical measurements, and (d) some renal hemodynamic parameters, in patients with essential hypertension.

\section{METHODS}

\section{Study design}

This was an open noncomparative study of amlodipine 5-10 mg once daily on 24-hour BP control, and its metabolic and renal effects, in outpatients with mild to moderate essential hypertension. The study consisted of 2 phases: a 2-week placebo run-in period (phase1) and an 8 -week active treatment with amlodipine (phase 2). The protocol was approved by the institutional ethical committee. Amlodipine tablets $(5 \mathrm{mg}$ ) were provided by Pfizer Indonesia, with the trade name of Norvask.

\section{Patients}

Men and women aged 21 - 65 years attending the hypertension outpatient clinic, with mild to moderate essential hypertension defined as a stable sitting diastolic BP (SiDBP) between 95 and $114 \mathrm{mmHg}$ (Korotkoff phase $\mathrm{V}$ ), were recruited in this study. Patients were either untreated or had previous antihypertensive therapy discontinued 2 weeks before entry into the study. Only patients whose mean SiDBP was 95-114 $\mathrm{mmHg}$ at the end of the placebo phase (phase 1) and had given their informed consent were eligible to enter the active treatment phase ( phase 2 ).

Patients with the following conditions were excluded from the study : renal dysfunction ( serum creatinine $2 \mathrm{mg} / \mathrm{dl}$ or more ), diabetes mellitus, congestive heart failure, ischemic heart disease, arrhythmias, hypertensive target organ damage, cerebrovascular disease, severe liver disease, malignancies, psychoses, infections, pregnancy, lactation, hypersensitivity to calcium antagonists of dihydropyridine class, or other conditions that would be hazardous to the patients health if included in this trial. These conditions were excluded by routine clinical examination.

\section{Study medication}

During phase 1, patients received placebo tablets of amlodipine $5 \mathrm{mg}$ once daily in the morning. Phase 2 started with amlodipine $5 \mathrm{mg}$ once daily in the morning. If after 2 weeks of treatment, the BP had not been adequately controlled ( DBP $>90 \mathrm{mmHg}$ or its lowering $<10 \mathrm{mmHg}$ from baseline value), the amlodipine dose was increased to $10 \mathrm{mg}$ once daily, except when some significant side effect(s) occurred.

\section{Casual BP}

Office BP and heart rate were measured every 2 weeks approximately 24 hours after the previous dose (trough effect). At each visit, BP was measured using a standard mercury sphygmomanometer after 5 minutes in the sitting and supine positions and after 2 minutes in the standing position (each value was the mean of 3 readings). Heart rate was determined from an average of 5 $\mathrm{RR}$ intervals on the ECG recording.

\section{Ambulatory BP monitoring (ABPM)}

At the end of placebo phase (baseline), and again at the end of treatment phase, ambulatory BP was measured for 24 - hour period with a noninvasive automated device (90207 ABP Monitor, Spacelabs Inc., USA). This device used a standard cuff that was programmed in this study to inflate automatically at 60-minute intervals from 23.00 until 5.00, and every 20 minutes from 5.00 until 23.00 .

The following parameters of ABPM were calculated :

1. Average SBP throughout 24 hours

2. Average DBP over 24 hours

3. Mean arterial pressure

$\left(\mathrm{MAP}=\frac{\mathrm{SBP}+2 \mathrm{DBP}}{3}\right)$ over 24 hours

4. Pulse pressure ( $\mathrm{PP}=\mathrm{SBP}-\mathrm{DBP}) 24$ hours

5. Heart rate 24 hours

\section{Hormonal and biochemical measurements}

At the end of placebo phase and also after 8 weeks of amlodipine treatment, the following laboratory measurements were carried out: plasma renin activity (PRA) and atrial natriuretic peptide (ANP), plasma insulin and glucose, plasma creatinine, sodium and potassium, and 24-hour urinary output of catecholamines (norepinephrine, NE and epinephrine, Epi ).

Venous blood was taken approximately 24 hours after the last dose, in fasting condition (for a minimum of 8 hours), after the patient had been sitting for 30 minutes. Measurements of the following hormones were carried out by radioimmunoassay (RIA) with their respective commercial kits: PRA ( after sitting for $30 \mathrm{~min}$ ) using Angiotensin I - Biotecx RIA Kit, plasma ANP using HANP Kit Eiken, insulin (after a minimum of 8 hours fast) with Coat-A-Count Insulin, and catecholamines (in 24-hour urine output) using Amicyl-Test Katcombi. 


\section{Renal hemodynamics}

Glomerular filtration rate (GFR) was measured by a single injection of $99 \mathrm{~m}$ Technetium-labelled diethylene-triaminepentaacetic acid, whereas effective renal plasma flow (ERPF) was determined by a single injection of 131 Iodine-labelled para-aminohippuric acid, at baseline and after 8-week treatment with amlodipine.

Concomitant medication with other antihypertensives or other drugs which would affect BP were not allowed. Salt intake was not restricted. Drug compliance was assessed by count of tablets returned at every visit. Any patient who interrupted the study medication for more than 5 days between 2 consecutive visits were withdrawn from the study. Any side effects reported were recorded together with concomitant drug administration.

\section{Data analysis}

Besides descriptive statistics, paired t-test was used to analyze the changes in casual BP and HR, ABPM parameters, hormonal and other biochemical values, and renal hemodynamic parameters, before and after amlodipine treatment.

\section{RESULTS}

\section{Patients}

Thirty patients ( 19 men and 11 women ) with a mean age of 47.8 years (range of $24-65$ years) and a mean body weight of $65.4 \mathrm{~kg}$ (range of $45-89 \mathrm{~kg}$ ) were recruited into this study. Almost all of the patients had hypertension for at least 2 years duration, and yet 13 patients were not on antihypertensive medication recently.

Six patients ( 2 men and 4 women ) did not complete the study due to reasons unrelated to the study drug, and therefore were excluded from the analysis of amlodipine effects on BP, HR and various laboratory values. Among 24 patients who completed the study, there were 17 men and 7 women; the mean age was 48.0 years (range 24 - 65 years) and the mean body weight was $65.1 \mathrm{~kg}$ ( range $45-89 \mathrm{~kg}$ ). All of them had at least 2.5 years duration of hypertension and 8 of them were not under antihypertensive treatment. Thirteen patients required an increase in dose to $10 \mathrm{mg}$ of amlodipine, while eleven remained on $5 \mathrm{mg}$ daily.

\section{Casual BP and HR}

The casual BP and HR values at baseline and after 8-week treatment with amlodipine are shown in Table 1. Amlodipine decreased casual BP in supine, sitting as well as standing positions $(p<0.001)$. There was no difference between supine and standing BP, indicating that amlodipine does not cause orthostatic hypotension. HR was not affected by amlodipine (Table 1). Changes in casual BP every 2 weeks from baseline until 8 weeks of treatment can be seen in Figure 1.

Table 1. Effects of amlodipine on casual BP and HR

\begin{tabular}{|c|c|c|c|c|c|c|c|}
\hline \multirow{2}{*}{ Parameter } & \multicolumn{5}{|c|}{ Mean \% SD $(n=24)$} & \multirow{2}{*}{ Paired $t$} & \multirow{2}{*}{$\mathrm{p}$} \\
\hline & \multicolumn{2}{|c|}{ Baseline } & \multicolumn{2}{|c|}{ Week-8 } & Difference & & \\
\hline \multicolumn{8}{|l|}{ 1. Systolic BP (mmHg) } \\
\hline - Supine & $164 \%$ & 13.1 & $134.9 \%$ & 11.6 & $29.2 \% 8.5$ & 16.78 & $<0.001$ \\
\hline - Sitting & $162.0 \%$ & 12.7 & $133.5 \%$ & 11.2 & $28.5 \% 8.2$ & 17.06 & $<0.001$ \\
\hline - Standing & $162.1 \%$ & 13.1 & $133.5 \%$ & 11.3 & $28.6 \% 8.6$ & 16.40 & $<0.001$ \\
\hline \multicolumn{8}{|l|}{ 2. Diastolic BP ( $\mathrm{mmHg})$} \\
\hline - Supine & $103.6 \%$ & 4.7 & $81.6 \%$ & 3.0 & $22.0 \% 4.2$ & 25.67 & $<0.001$ \\
\hline - Sitting & $104.6 \%$ & 4.6 & $82.4 \%$ & 3.2 & $22.2 \% 3.9$ & 28.22 & $<0.001$ \\
\hline - Standing & $105.1 \%$ & 5.0 & $82.1 \%$ & 3.1 & $23.0 \% 4.6$ & 24.36 & $<0.001$ \\
\hline 3. Supine HR (bpm) & $78 \%$ & 9.7 & $78.7 \%$ & 8.8 & $-0.2 \% 8.8$ & -0.17 & NS \\
\hline
\end{tabular}

NS = Not significant 


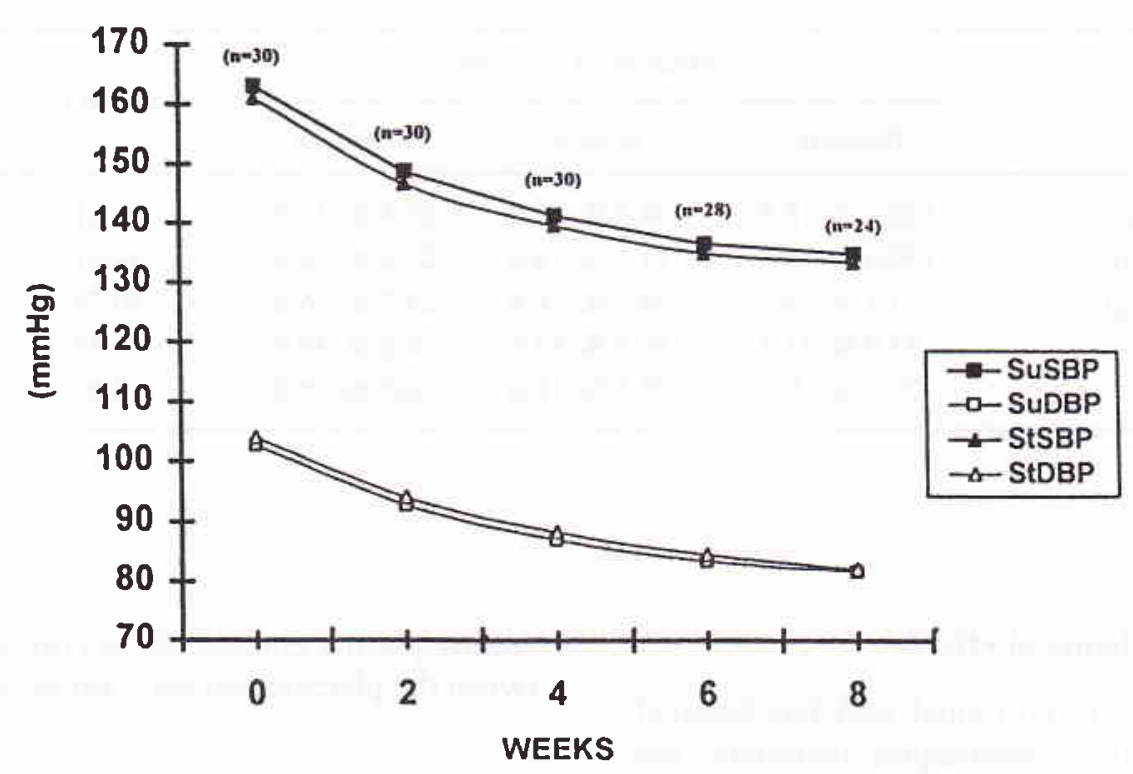

Figure 1. Mean supine and standing systolic and diastolic BP over 8 weeks of treatment. Number along the axis indicates number of patients at each time of observation

\section{Ambulatory BP monitoring}

The average hourly SBP, DBP and HR over a 24 hour period are shown in Figure 2. A reduction in SBP and DBP was observed throughout the 24 - hour period after treatment with amlodipine compared to baseline without altering the circadian pattern. No significant changes in HR were observed.
Comparison of ABPM parameters before and after amlodipine treatment can be seen in Table 2. Amlodipine decreased SBP, DBP, MAP and PP throughout 24 hours significantly, while HR was essentially unchanged.

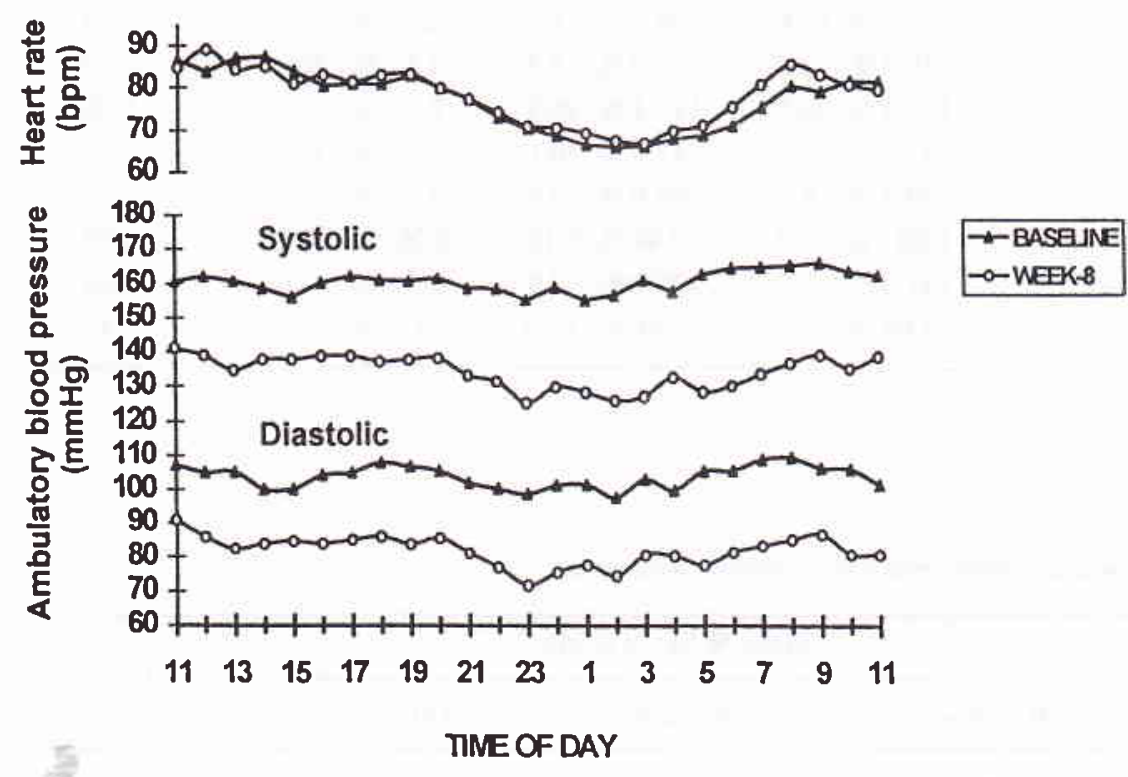

Figure 2. Average hourly SBP, DBP and HR over a 24-hour period using ABPM $(n=24)$ before and after 8 weeks therapy with amlodipine 
Table 2. Effects of amlodipine on ABPM parameters

\begin{tabular}{|c|c|c|c|c|c|}
\hline \multirow{2}{*}{ Parameter } & \multicolumn{3}{|c|}{ Mean $\%$ SD $(n=24)$} & \multirow{2}{*}{ Paired $t$} & \multirow{2}{*}{$\mathrm{p}$} \\
\hline & Baseline & Week-8 & Difference & & \\
\hline 1. SBP 24 hours $(\mathrm{mmHg})$ & $160.6 \% 15.9$ & $134.3 \% 12.7$ & $26.4 \% 10.9$ & 11.81 & $<0.001$ \\
\hline 2. DBP 24 hours (mmHg) & $130.6 \% \quad 5.5$ & $81.7 \% \quad 4.0$ & $21.9 \% \quad 4.4$ & 24.61 & $<0.001$ \\
\hline 3. MAP 24 hours ( $\mathrm{mmHg}$ ) & $123.1 \% \quad 9.3$ & $99.5 \% \quad 6.4$ & $23.7 \% \quad 5.6$ & 20.76 & $<0.001$ \\
\hline 4. PP 24 hours $(\mathrm{mmHg})$ & $57.0 \% 11.7$ & $52.4 \% 11.6$ & $4.5 \% \quad 10.0$ & 2.22 & $<0.05$ \\
\hline 5. HR 24 hours (bpm) & $77.7 \% \quad 9.7$ & $78.5 \% \quad 9.6$ & $-0.9 \% \quad 6.5$ & -0.66 & NS \\
\hline
\end{tabular}

NS $=$ Not significant

\section{Hormonal and biochemical effects}

Comparison of various hormonal and biochemical values before and after amplodipine treatment are shown in Table 3. Sitting PRA, plasma ANP, and fasting plasma insulin increased slightly ( $p<0.05$ to $<0.001$ ), while plasma creatinine, plasma sodium and potassium decreased slightly ( $\mathrm{p}<0.01$ to $<0.001$ ). Urinary norepinephrine and epinephrine, as well as fasting plasma glucose did not differ significantly between the placebo and amlodipine phases.

\section{Renal hemodynamics}

After 8 weeks of amlodipine therapy, GFR as well ERPF increased slightly $(\mathrm{p}<0.001)$ compared to baseline (Table 4).

Table 3. Effects of amlodipine on hormonal and biochemical values

\begin{tabular}{|c|c|c|c|c|c|}
\hline \multirow{2}{*}{ Parameter } & \multicolumn{3}{|c|}{ Mean $\%$ SD $(n=24)$} & \multirow{2}{*}{ Paired t } & \multirow{2}{*}{$\mathrm{p}$} \\
\hline & Baseline & Week-8 & Difference & & \\
\hline PRA (ng/ml/h) & $1.74 \% \quad 0.56$ & $1.89 \% \quad 0.54$ & $-0.15 \% \quad 0.11$ & -6.89 & $<0.001$ \\
\hline Plasma ANP (pg/ml) & $52.1 \% 12.6$ & $54.7 \% \quad 11.0$ & $-2.6 \% \quad 5.5$ & -2.31 & $<0.05$ \\
\hline Plasma insulin $(\mu \mathrm{U} / \mathrm{ml})$ & $19.9 \% \quad 4.2$ & $21.0 \% \quad 4.3$ & $-1.1 \% \quad 0.8$ & -6.72 & $<0.001$ \\
\hline Urinary NE (nmol/24 h) & $115.4 \% 24.6$ & $113.2 \% 20.8$ & $2.2 \% 10.2$ & 1.06 & NS \\
\hline Urinary Epi (nmol/24 h) & $45.6 \% 11.0$ & $43.9 \% 10.1$ & $1.7 \% 8.9$ & 0.92 & NS \\
\hline Plasma glucose (mg/dl) & $97.3 \% \quad 8.6$ & $99.0 \% \quad 7.1$ & $-1.7 \% \quad 6.3$ & -1.32 & NS \\
\hline Plasma creatinine (mg/dl) & $1.00 \% \quad 0.17$ & $0.94 \% 0.18$ & $0.06 \% 0.07$ & 3.98 & $<0.001$ \\
\hline Plasma sodium (mEq/l) & $141.0 \% \quad 3.3$ & $139.0 \% \quad 2.9$ & $2.0 \% 1.1$ & 8.88 & $<0.001$ \\
\hline Plasma potasium (mEq/) & $3.98 \% \quad 0.31$ & $3.86 \% \quad 0.31$ & $0.11 \% 0.16$ & 3.45 & $<0.01$ \\
\hline
\end{tabular}

NS $=$ Not significant

Table 4. Effects of amlodipine on some renal hemodynamic parameters

\begin{tabular}{lcccccc}
\hline \multirow{2}{*}{ Parameter } & \multicolumn{3}{c}{ Mean \% SD $(\mathrm{n}=24)$} & Paired t & p \\
\cline { 2 - 5 } & Baseline & Week-8 & Difference & & \\
\hline GFR (ml/min) & $112.1 \% 11.5$ & $115.8 \% 11.6$ & $-3.7 \% 2.3$ & -7.79 & $<0.001$ \\
ERPF (m1/min) & $552.0 \% 55.8$ & $595.2 \% 52.9$ & $-43.2 \% 17.1$ & -12.34 & $<0.001$ \\
\hline
\end{tabular}




\section{Side effects}

Six out of 30 patients experienced adverse effects during amlodipine treatment. Mild edema occurred in 2 patients and mild dizziness in 1 patient after the dose was increased to $10 \mathrm{mg}$, and disappeared after dose reduction to $5 \mathrm{mg}$ while BP control was maintained.

Mild tolerated fatigue occurred in 1 patient at $10 \mathrm{mg}$ dose, 1 patient had mild flushing at $5 \mathrm{mg}$ which was tolerated, and another patient got mild tolerated headache also at $5 \mathrm{mg}$ dose.

\section{DISCUSSION}

The result of the present study show that once daily dosage of amlodipine significantly lowered casual BP at 24 - hour postdose, without increasing heart rate. Amlodipine did not cause orthostatic hypotension, which indicates that peripheral venodilation did not occur. Ambulatory BP monitoring provides a better picture in the evaluation of antihypertensive treatment. ${ }^{9-13}$ The finding of this study shows clearly that once-daily amlodipine is effective in lowering BP throughout a 24-hour peroid, without altering the physiologic circadian pattern of BP variation. These results confirm the previous findings ${ }^{14-17}$ and provide strong support for amlodipine use as once-daily therapy. Amlodipine did not cause reflex tachycardia and produced a low incidence of acute vasodilatory side effects (dizziness, flushing, headache), due to its slow onset of action. ${ }^{1,3,18}$

Recent advances indicate that atrial natriuretic peptide play important roles in blood pressure homeostasis, both in normal and in pathophysiological conditions. ${ }^{19,20}$ The renin-angiotensin system has been considered as a hormonal system with a major role in blood pressure and volume regulation. ${ }^{21,22} \mathrm{Sym}$ pathetic overactivity has been demonstrated in patients with essential hypertension and imbalances in several neurotransmitters and neuromodulators are present during the development of hypertension. ${ }^{23,24}$

In the present study, 8 weeks therapy with amlodipine $5-10 \mathrm{mg}$ in mild to moderate essential hypertension which effectively normalized systolic and diastolic BP caused little if any change in the plasma levels of renin and atrial natriuretic peptide as well as urinary excretion of norepinephrine and epinephrine. Albernethy et al. ${ }^{25}$ also found similiar levels of plasma renin, ANP, NE and Epi at baseline, 2 week, and 14-week of amlodipine therapy. No significant change in PRA was also observed by Reams et al. ${ }^{26}$ after 6 weeks therapy with amlodipine. Cappuccio et al., ${ }^{27}$ however, found a significant increase in PRA (more than twice) and a significant decrease in ANP (almost half) from respective baseline values after only 2 weeks of amlodipine treatment. The absence of changes in plasma renin and catecholamine levels in patients with hypertension was also observed by Donati et al. ${ }^{28}$ after 8 weeks of amlodipine therapy. On the other hand, Packer et al. ${ }^{29}$ found that in patients with mild to moderate heart failure, 2 months therapy with amlodipine caused a significant decrease in plasma NE.

The current interest concerns linking hypertension to hyperinsulinemia and insulin resistance through increase vascular resistance. ${ }^{30,31}$ The present study show that in patients with essential hypertension, 8 weeks therapy with amlodipine did not alter fasting plasma levels of insulin and glucose. This result is in agreement with previous observations that amlodipine did not change fasting plasma levels of insulin and glucose in non-obese, normotensive young $\mathrm{men}^{32}$ as well as in obese hypertensive patients. ${ }^{33}$

Our results show that in patients with essential hypertension and normal renal function, 8 weeks of amlodipine therapy only slightly increased GFR and ERPF. Previous observations have indicated that calcium antagonist administration (both acute and chronic) in essential hypertensive patients caused either an increase or no change in GFR as well as ERPF. Furthermore, patients having the most functional impairment of renal function demonstrated the greatest renal response to calcium antagonists. ${ }^{26}$,

We found no clinically significant alterations in plasma creatinine, plasma sodium and potassium. The same results were observed by Ferrari et al. ${ }^{32}$ No change in creatinine clearance, plasma sodium and potassium was also found by Donati et al. ${ }^{28}$ Reams et al., ${ }^{26}$ however, found slight reduction in serum potassium concentration $(0.2 \mathrm{mEq} / \mathrm{l})$, although serum sodium and creatinine clearance did not change significantly.

In summary, the results of the present study were as follows. In patients with mild to moderate essential hypertension with normal renal function, antihypertensive treatment with amlodipine $5-10 \mathrm{mg}$ once daily as monotherapy for 8 weeks,

a) provided an effective BP control throughout 24 hours without altering the physiologic circadian 
pattern of BP variation, did not cause orthostatic hypotension nor reflex tachycardia

b) was well tolerated

c) was not associated with clinically significant changes in PRA, plasma ANP, urinary excretion of NE and Epi, fasting plasma insulin and glucose, plasma creatinine, sodium and potassium.

d) was not associated with significant increase in GFR and ERPF.

\section{CONCLUSIONS}

We conclude that amlodipine once daily is an effective antihypertensive throughout 24 hours without altering the circadian variation, and is well tolerated, for monotherapy of mild to moderate hypertension. The drug has no significant effect on pressor hormones, glucose metabolism, nor renal function.

\section{REFERENCES}

1. Meredith PA, Elliott HL. Cinical pharmacokinetics of amlodipine. Clin Pharmacokinet 1992; 22(1): 22-31.

2. Meredith PA, Elliott HL. Amlodipine: Clinical relevance of a unique pharmacokinetic profile. J Cardiovasc Pharmacol 1993; 22 (Suppl A): S6 - S8.

3. Bremner AD, Fell PJ, Hosie J, James IGV, Saul PA, Taylor SH. Early side-effects of antihypertensive therapy: comparison of amlodipine and nifedipine retard. J Hum Hypertens 1993; 7: 79-81.

4. Laragh JH, Held C, Messerli F, Pepine C, Sleight P. Calcium antagonists and cardiovascular prognosis: a homogeneous group? Am J Hypetens 1996; 9: 99-109.

5. Epstein M. Calcium antagonists: still appropriate as first line antihypertensive agents. Am J Hypertens 1996; 9: 11021.

6. Epstein M. Calcium antagonists and renal protection : current status and future prospectives. Arch Intern Med 1992; 152: 1573-84.

7. Trost BN, Weidmann P. Metabolic effects of calcium antagonists in humans, with emphasis on carbohydrate, lipid, potassium and uric acid homeostatis. $\mathrm{J}$ Cardiovasc Pharmacol 1988; 12 (Suppl6): S86- S92.

8. Beer NA, Jakubowicz DJ, Beer RM, Arocha IR, Nestler JE. Effects of nitrendipine on glucose tolerance and serum insulin and dehydroepiandrosteron sulfate levels in insulin-resistant obese and hypertensive men. J Clin Endocrinol Metab 1993; 76: 178-83.

9. Mancia G, Casader R, Mutti E, Trazzi S, Parati G. Ambulatory blood pressure monitoring in the evaluation of antihypertensive treatment. Am J Med 1989; 87 (Suppl 6B): S64-S69.

10. Pickering T. Recommendations for the use of home (self) and ambulatory blood pressure monitoring. Am J Hypertens 1996; 9: 1-11.

11. Verdecchia P, Porcellati C, Schillaci G, et al. Ambulatory blood pressure. An independent predictor of prognosis in essential hypertension. Hypertension 1994; 24 : 793-801.

12. Sheps SG, Clement DL, Pickering TG, et al. ACC position statement. Ambulatory blood pressure monitoring. J Am Coll Cardiol 1994; 23: 1511-3.

13. Mansoor GA, White WB. Ambulatory blood pressure monitoring in current clinical practice and research. Curr Opin Nephrol Hypertens 1995; 4: 531-7.

14. Mroczek WJ, Burris JF, Allenby KS. A double - blind evaluation of the effect of amlopidine on ambulatory blood pressure in hypertensive patients. J Cardiovasc Pharmacol 1988; 12 (Suppl 7): S79-S84.

15. Heber ME, Brigden G, Al-Khawaja I, Raftery EB. 24-hour blood pressure control with the once daily calcium antagonist, amlodipine. Br J Clin Pharmacol 1989; 27: 359-65.

16. Lorimer AR, Smedsrud T, Walker P, Tyler HM. A comparison of amlodipine, verapamil and placebo in the treatment of mild to moderate hypertension. J Hum Hypertens 1989; 3: 191-6.

17. Lacourciere $Y$, Poirier L, Provencher P. Comparison of the effects of amlodipine, and captopril on clinic and ambulatory blood pressure. J Hum Hypertens 1992; 6 (Suppl 1): S25-S28.

18. Deanfield JE, Detry JMRG, Lichtlen PR, Magnani B, Sellier $P$, Thaulow E. Amlodipine reduces transient myocardial ischemia in patients with coronary artery disease: double-blind circadian anti-ischemia program in Europe (CAPE Trial). J Am Coll Cardiol 1994; 24: 1460-7.

19. Nakao K, Itoh H, Saito Y, Mukoyama M, Ogawa Y. The natriuretic peptide family. Curr Opin Nephrol Hypertens 1996; 5: 4-11.

20. Prins BA, Biesiada E, Levin ER. Natriuretic peptides and hypertension. Curr Opin Nephrol Hypertens 1996; 5: 170-3.

21. Paran E, Nemenoff RA, Schrier RW. Role of the renin-angiotensin system in essential hypertension. Curr Opin Nephrol Hypertens 1995; 4: 295-9.

22. Braam B, Koomans HA. Renal responses to antagonism of the renin-angiotensin system. Curr Opin Nephrol Hypertens 1996; 5: 89-96.

23. Wyss JM. The role of the sympathetic nervous system in hypertension. Curr Opin Nephrol Hypertens 1993; 2: 265-73.

24. Saruta T, Kumagai H. The sympathetic nervous system in hypertension and renal disease. Curr Opin Nephrol Hypertens 1996; 5: 72-9.

25. Albemethy DR, Gutkowska J, Lambert MD. Amlodipine in elderly hypertensive patients: pharmacokinetics and pharmacodynamics. J Cardiovasc Pharmacol 1988; 12 (Suppl 7): S67-S71.

26. Reams GP, Lau A, Hamory A, Bauer JH. Amlodipine therapy corrects renal abnormalities encountered in the hypertensive state. Am J Kidney Dis 1987; 10(6): 446-51.

27. Cappuccio FP, Markandu ND, Sagnella GA, et al. Effects of amlodipine on urinary sodium excretion, renin-angiotensin-aldosterone system, atrial natriuretic peptide and blood pressure in essential hypertension. J Hum Hypertens 1991; $5: 115-9$.

28. Donati L, Buhler FR, Beretta - Piccoli C, Kusch F, Heinen G. Antihypertensive mechanism of amlodipine in essen- 
tial hypertension: role of pressor reactivity to norepinephrine and angiotensin II. Clin Pharmacol Ther 1992; 52(1): 50-9.

29. Packer M, Nicod P, Khandheria BR, et al. Randomized, multicenter, double-blind, placebo-controlled evaluation of amlodipine in patients with mild-to-moderate heart failure (Abstract). JACC 1991; 17(2): 274A.

30. Baron AD. Pathogenesis and measurement of insulin resistance in hypertension. Curr Opin Nephrol Hypertens 1994; 3: 631-5.

31. Susalit E, Sidabutar RP. Haemodynamic and humoral profiles of Indonesian elderly hypertensive patients. Med J Indones 1995; 4: 48-52.

32. Ferrari P, Giachino D, Weidmann $P$, et al. Unaltered insulin sensitivity during calcium channel blockade with amlodipine. Eur J Clin Pharmacol 1991; 4: 109-13.
33. De Courten M, Ferreri P, Schneider M, et al. Lack of effect of long-term amlodipine on insulin sensitivity and plasma insulin in obese patients with essential hypertension. Eur $\mathrm{J}$ Clin Pharmacol 1993; 44: 457-62.

34. Bauer JH, Reams GP. Renal protection with calcium antagonism in essential hypertension. Clin Investigative Med 1989; 12(5): 300-4.

35. Sunderrajan S, Reams GP, Bauer JH. Renal effects of diltiazem in primary hypertension. Hypertension 1986; 8: 238-42.

36. Sunderrajan S, Reams GP, Bauer JH. Long-term renal effect of diltiazem in essential hypertension. Am Heart J 1987; 114: 383-8.

37. Reams GP, Harmony A, Lau A, Bauer JH. Effect of nifedipine on renal function in patients with essential hypertension. Hypertension 1988; 11: 452-6. 